\title{
RECENZJE
}

\section{Ks. Franciszek LongChamps de BéRIer, Powtórka $z$ Rzymu, Bielsko-Biała, Kraków 2017, ss. 214}

Genialny francuski malarz Paul Cezanne miał powiedzieć krótko przed śmiercią: „Dać obraz tego, co widzimy, zapominając wszystko, co się przed nami ukazało. To, zdaje się, powinno pozwolić artyście na ukazanie całej swojej osobowości małej czy wielkiej”. Choć słowa te można odnieść do każdej dziedziny życia, wyjątkowo dobrze charakteryzują one specyfikę twórczości naukowej profesorów prawa rzymskiego. Korzystając wciąż z tych samych źródeł, mimowolnie skazani jesteśmy na nieustanne powtarzanie tego, co już wielokrotnie powiedzieli inni. Od łatki pozbawionych refleksji naśladowców może nas jednak uchronić wyrafinowany sposób przekazu połączony z wytyczeniem niestandardowych trajektorii, jakimi następnie puścimy w ruch naszą myśl. Jakże bardzo krótkie formy, takie jak esej czy felieton, nadają się do wydobycia niezliczonych wartości zamkniętych w prawie rzymskim! Jak dobrze pozwalają one oddać całą jego subtelność! Ich formuła, zakładająca chęć szybkiego dotarcia do masowego czytelnika, ex definitione wiążącego lekturę z rozrywką, daje niepowtarzalną szansę zainteresowania odbiorcy, który z własnej woli po podręcznik prawa rzymskiego nigdy by nie sięgnął. Paradoksalnie, u takich właśnie czytelników najłatwiej wywołać efekt ekstatycznego zachłyśnięcia się prawem rzymskim, co sprawia, że w ich umysłach dochodzi do przedziwnej transformacji. Oto bowiem z obojętnych laików w mgnieniu oka zmieniają się w najbardziej zagorzałych pasjonatów i obrońców iuris Romani. O tym wszystkim wielokrotnie rozmyślałem, przygotowując prace „lekkie”, mające charakter popularyzatorski. Po lekturze zbioru tekstów autorstwa księdza profesora Franciszka Longchamps de Bérier, opatrzonych tytułem „Powtórka 
z Rzymu”, zastanawiam się, o czym myślał on, kiedy przelewał na papier refleksje, z którymi obcowanie tak potwornie mnie umęczyło.

Zacznijmy jednak od początku. Książka, jak wspomniano, nosi tytuł „Powtórka z Rzymu”, a składa się na nią pięćdziesiąt krótkich form, regularnie ogłaszanych przez autora na łamach „Rzeczy o prawie” (dodatek do „Rzeczpospolitej”). Pod względem edytorskim, za co słowa szczerego uznania należą się Wydawnictwu Od.Nowa, przygotowano ją wspaniale. Twarda płócienna oprawa, papier przyjemny dla oka i opuszek palców oraz niebanalne ilustracje Andrzeja Krauzego czynią z niej produkt luksusowy. Formalna jakość publikacji, co również zasługuje na szczególne podkreślenie, nie koresponduje z jej ceną. Czytelnik płaci bowiem za dzieło o wiele mniej, niż należałoby się spodziewać. Gdybyż forma choć w części znalazła odbicie w treści... Niestety, w tej drugiej razi mnie niemal wszystko, a zwłaszcza: sposób budowania narracji, dzikie skojarzenia, ton, jakim wygłaszane są komunały oraz nonszalanckie dopatrywanie się ukrytych znaczeń tam, gdzie ich nie ma. Pragnę przy tym zastrzec, że nie zamierzam dyskutować z poglądami i aluzjami natury politycznej, religijnej oraz światopoglądowej, od których autor nie stroni w swoich rozważaniach. Podjęcie dialogu na tym poziomie będzie możliwe po naniesieniu przez Autora odpowiednich korekt.

Przejdźmy do konkretów. Piętą achillesową księdza profesora ewidentnie jest łacina. W felietonie zatytułowanym „Antyfeminizm nieuwagi” autor zapewnia, że nie zamierza nikogo pouczać, a następnie poucza, i to w sposób pryncypialny (ss. 29-31). Bombastyczny tytuł przyporządkowano rozważaniom, z których zrozumiałem jedynie słownikową informację, że rzeczowniki łacińskie zakończone na -io są rodzaju żeńskiego, a autorowi nie podoba się, gdy ktoś nie wie, że do tego samego rodzaju należy przyporządkować takie wyrażenia, jak ratio legis, vacatio legis, ignorantia iuris oraz conditio sine qua non (podobne natręctwo pojawia się na s. 46: „na marginesie: rzeczownik lex jest rodzaju żeńskiego”). W podsumowaniu czytamy: „W przypadku łaciny ignorancja faktów szkodzi natychmiast. Grozi ośmieszeniem mówiącego lub piszącego prawnika, który pragnie uchodzić za wykształconego lub przekonującego" (ss. 30-31). Tymczasem kilka stron dalej pojawia się na zdanie: „De domo sua cieszy, że prawo rzymskie znalazło się ostatnio 
w wirze dyskusji nie tylko amerykańskiej literatury z zakresu ekonomii i finansów” (s. 34). Podobnie na stronie 53: „W stanie faktycznym z nec stultis solere succurri testator zapisał pieniądze na budowę akweduktu w północnoafrykańskim mieście Cirta”. Strona 163: „W starożytnym Rzymie nemo iudex to silny argument na rzecz ograniczania samodzielnego i samowolnego dochodzenia praw, zwłaszcza samopomocy ofensywnej zwaną zaczepną". Przypomina mi się zasłyszana historia biednej studentki naszej filologii klasycznej, która podczas egzaminu z szalenie poważną miną oświadczyła: „U Liwiusza nie ma expressis verbis”. Sprawę załatwiono ekspresowo: wyleciała za drzwi z dwóją w indeksie.

Dwa słowa na temat terminologicznej ścisłości. Poważnie zastanowiłbym się, czy słowo peccatum we fragmencie rozprawy Cycerona „O powinnościach” należy rozumieć jako błąd. Na stronie 25, wśród niepowiązanych ze sobą fantazji na temat Kmicica, klauzuli rebus sic stantibus, zasady pacta sunt servanda oraz Chrystusowego nauczania, czytamy: „Cycerona - 100 lat przed Seneką - zajmował kazus: »jeśli ktoś, będąc zdrowy na umyśle, zdeponował u ciebie miecz, a żąda zwrotu będąc w obłędzie, oddać jest błędem (peccatum), nie oddać obowiązkiem «". Rzućmy okiem na oryginał: Si gladium quis apud te sana mente deposuerit, repetat insaniens, reddere peccatum sit, officium non reddere (de off. 3.95). Skąd tu błąd? Dlaczego błąd? Rzeczownik peccatum, zanim łacina kościelna dokonała jego znaczeniowej monopolizacji, wykorzystywany był w różnorakich kontekstach. W naszym nie będzie on z pewnością oznaczał błędu, ale winę, występek, przestępstwo. Porównajmy: „Jeśli ktoś, będąc zdrowy na umyśle, zdeponował u ciebie miecz, a żąda zwrotu będąc w obłędzie, oddać jest przestępstwem, nie oddać obowiązkiem”. Teraz fraza brzmi prawidłowo. Strona 78: „custos to nawet nie tyle stróż, co piastun". Otóż, nie: i stróż, i strażnik, i piastun, a nawet ochroniarz osobisty (por. custos corporis Caesaris). Dla sicarii, o których wspomina ustawodawstwo Sulli, z pewnością da się znaleźć lepszy polski ekwiwalent od „sztyletowców” (s. 82). Na stronie 156 w następujący sposób przełożono fragment autorstwa Modestyna: „przestępstwa pozwanych podlegają abolicji na podstawie prawa łaski”. W wersji łacińskiej fraza przyjmuje brzmienie: indulgentia crimina reorum abolita sunt (D. 48.16.17). Abstrahując od wieloznaczności pojęć 
abolitio (w zależności od kontekstu: amnestia, ułaskawienie, abolicja) oraz reus (pozwany, oskarżony, zasądzony, skazany, podejrzany) oraz stylistycznej i logicznej ułomności tłumaczenia, pisanie w prawniczym piśmie na temat „przestępstw pozwanych” wprawia w osłupienie. Czy na Uniwersytecie Jagiellońskim studenci pierwszego roku prawa mają jeszcze szansę dowiedzieć się, jaka jest różnica pomiędzy powodem i oskarżycielem, pozwanym i oskarżonym, powództwem i aktem oskarżenia, zasądzeniem i skazaniem itd.?

Wątpliwości budzi sposób spojrzenia autora na niektóre łacińskie paremie. Zamieszanie spowodowane poszukiwaniem nowej polskiej wersji dla maksym ius civile vigilantibus scriptum est (ss. 53-54) oraz iurisprudentia est divinarum atque humanarum rerum notitia, iusti atque iniusti scientia (s. 101) można jeszcze jakoś przeboleć, ale oto na stronie 174 formuła apices iuris non sunt iura oddana została jako „rozwiązania skrajne w prawie nie są prawami”. Maksyma ta w piśmiennictwie epoki nowożytnej ma jednak zupełnie inne znaczenie. Apices iuris to osławione „kruczki prawne”. Rzućmy okiem na wersję tradycyjną: Apices iuris non sunt iura - „Kruczki prawne nie są prawem”. Zdanie nareszcie ma sens, prawda? Należy podkreślić, że autor nieźle daje sobie radę ze spolszczeniem takich zasad i fraz jak: nemo dat qui non habet (s. 21), impossibilium nulla obligatio (s. 21), nasciturus pro iam nato habetur, quotiens de commodis eius agitur (s. 41), iustitia est constans et perpetua voluntas ius suum cuique tribuendi (s. 77), lex est quod notamus (s. 77), simplicitas legibus amica (s. 81), mater semper certa est, pater is est, quem nuptiae demonstrant (s. 93), quod bonum, felix, faustum, fortunatumque sit (s. 146), male nostro iure uti non debemus (s. 150), non omne quod licet, honestum est (s. 150), ius est ars boni et aequi (s. 150), nemo iudex in causa sua (s. 161). Jaki z tego wniosek? Otóż taki, że za każdym razem, kiedy ksiądz profesor Franciszek Longchamps de Bérier podąża za ukochaną tradycją i przytacza powszechnie przyjęte znaczenia wyrazów i fraz, jest dobrze. Kiedy jednak usiłuje przy nich majstrować na własną rękę, zaczynają się problemy.

Tłumaczenie ze wszystkich języków obcych, nie tylko z łaciny, na zasadzie idem peridem stanowi błąd warsztatowy. Strona 58: „Paradoksalnie zaś projekt może wpłynąć na unormowania w Rosji, gdzie został 
przetłumaczony, aby dać rosyjskiemu prawu prywatnemu ramę odniesienia”. Owszem, mamy common frame of reference, ale pisząc o „ramie odniesienia" stajemy w jednym rzędzie z Podkomorzyną Niemcewicza, uskarżającą się na migrenę słowami: „głowa źle mi zrobiła”. Z punktu widzenia zasad poprawnej polszczyzny „punkt odniesienia” o wiele lepiej pasuje do kwestionowanego zdania.

Ciężkie westchnienie wywołują próby nowatorskiego ujęcia pewnych doskonale znanych formuł i pojęć. „Prekarium to »używanie z uproszenia «", czytamy na stronie 65 . Na stronie 86 po trzykroć szczęśliwy autor przekonuje, że wie, „czym różni się mam od posiadam”. „Po śmierci Heroda” - napisano na stronie 106 - „skłóceni książęta żydowscy poprosili o rozstrzygnięcie Pompejusza. Wykorzystał okazję i w roku 6 po Chrystusie Judea stała się rzymską prowincją". Herod zmarł w 4 roku p.n.e. Pompejusz, kojarzony głównie z Gnejuszem Pompejuszem Wielkim, stracił życie w roku 48 p.n.e. Faktycznie Judea znalazła się pod pełną kontrolą Rzymian w wyniku tzw. Wojny Warusa trwającej od wiosny do lata roku 4 p.n.e. O co chodzi...? A teraz prawdziwa perełka: „w Rzymie małżeństwo nie było instytucją prawną ani nawet społeczną. Wynikało z tradycji, ale niosło szereg prawnych konsekwencji” (s. 131). Na stronie 169 sensacja: „Cesarz Oktawian tak wpłynął na rozwój prawa rzymskiego, że wyznaczył jego periodyzację”. Równie ciekawie jest na stronie 182: „autonomiczny zawód prawnika wynaleziono właśnie w Rzymie, gdzie czynnikiem prawotwórczym nie był wyrok, ale porada prawnika”. Zamiast pani, która na klasyce opowiadała o Liwiuszu, stają mi teraz przed oczyma zastępy pierwszoroczniaków, których osobiście popędziłem na cztery wiatry za wygłaszanie podczas kolokwiów podobnych opinii. Bywało jednak i odwrotnie. Strona 206: „Najpóźniej w czasach Justyniana słowo kodeks kojarzone jest jeśli nie wyłącznie, to przede wszystkim ze zbiorem przepisów prawnych”. Za coś podobnego to ja otrzymałem burę na zajęciach ze wstępu do historii sztuki i od tego czasu wiem, że podstawowym znaczeniem słowa codex jest w okresie poklasycznym „księga”. Ten stan rzeczy utrzymuje się zresztą i potem. W średniowieczu i we wczesnej epoce nowożytnej zbiorom prawa również nadawano raczej miana: speculum, decretum, 
costitutio, corpus itd. Zjawisko, na które zwrócił uwagę autor, przypada dopiero na wiek XVIII.

Przejdźmy do stylistyki. Autor bardzo trafnie zauważa, że w używanym języku bywamy „porażająco prawdziwi” (s. 45). Oj, tak... Nie odniosę się do maniery pisarskiej księdza profesora Franciszka Longchamps de Bériera, choć Czytelnik zdążył się już zapewne domyślić, że nie jest mi ona bliska. Każdy niech pisze, jak chce i umie. Chciałbym natomiast zwrócić uwagę na pewne językowe niezręczności, których w moim odczuciu - dało się uniknąć i które nie wystawiają autorowi najlepszego świadectwa. Strona 22 przenosi nas do świata frazeologii Polski gomułkowskiej: „współcześnie jedno z pól zastosowania naszej reguły przyniosła kwestia...”. W tym samym klimacie utrzymuje nas zdanie ze strony 61: „Młodzież szturmująca na »kierunku chińskim« patrzy daleko”. Na stronie 89 zagaja autor zalotnie: „Praca powinna cieszyć, lecz radość miesza się z wahaniem, jakie zawsze wynika z zaskoczenia »nowymi« książkami nieżyjących autorów. Zdarzają się ostatnio na rynku i nie o prawie teraz myślę. Jest przecież coś niepokojącego w tym, że ludzie dawno odeszli, a teksty nieogłaszane dotąd drukiem ukazują się w sposób, który każe uważać je za wydarzenia na dużą skalę”. Strona 93: „Problematyczne mogło być, jakiego mężczyzny nie wolno przywieść na drogę sądową”. Strona 158: „Starożytni opanowali siedem grzechów głównych w stopniu niemal doskonałym”. To wszystko jednak nic. Zdanie, które bezapelacyjnie zgarnia wszystkie nagrody w kategorii monstrum, brzmi: „Rzymianie najwyraźniej nie byli w stanie tolerować zabierania się z ostrymi narzędziami do genitaliów” (s. 82).

W odrębnym akapicie pozwolę sobie na wypowiedź odnośnie do tekstu, który został zadedykowany między innymi mnie. W artykule postulującym totalne zastąpienie oznaczeń p.n.e. oraz n.e. przez „przed Chrystusem” i „po Chrystusie” autor konkluduje: „Niewiedza, dezorientacja, niechęć? Chronologiczne odwołanie się do Chrystusa jest neutralne, bo bez wartościowania ery czy uznawania roku za »Pański«. Jest intelektualnie uczciwe, gdyż szczere i konkretne. Chodzi o ustaloną w VI wieku i tradycyjnie przyjętą datę historycznego wydarzenia narodzin, gdzie rok 1 to rok 754 od założenia Rzymu. Tym trudniej doprawdy zrozumieć, dlaczego oznaczenia p.n.e. oraz n.e. pojawiają 
się w pracach naukowców z katolickich uczelni, na które zbieramy po kościołach tacę w drugi dzień Bożego Narodzenia” (s. 171). Gdybym to ja chciał zestawić wszystkie działania i wypowiedzi księdza Franciszka Lonchamps de Bérier, których nie rozumiem ani jako „naukowiec”, ani jako chrześcijanin, nie wiem, czy ogrom materii pomieściłby zeszyt specjalny niniejszego periodyku. Naturalnie, nikt mi czegoś podobnego nie wyda, ale pofantazjować miło. Opatrzyłbym go tytułem: Quaestiones prenatales et quaedam alia.

Reasumując, po zakończeniu „Powtórki z Rzymu” ogarnął mnie smutek bezbrzeżny. Poczułem to samo, czego swego czasu doświadczyła rosyjska pisarka Lidia Czukowska i czemu dała wyraz w słowach: „Przeczytać mogę, ale dowiedzieć się czegokolwiek - nie. Litery układają się w słowa, słowa w wiersze, wiersze w akapity, akapity w artykuły, ale nic nie układa się w myśli, uczucia, obrazy”. Liczba pięćdziesięciu felietonów, na jakiej autor poprzestał komponując swoje dzieło, w sferze numerologii nawiązuje do pięćdziesięciu ksiąg justyniańskich Digestów. Na tym jednak analogie się kończą. W recenzowanej książce nie ma słabych momentów. Ona sama jest jednym wielkim słabym momentem. Teksty poprawne, które mi się podobały i które przeczytałem ze względnym spokojem („Ćwiczenia z prawniczego myślenia”, ss. 37-39; „Kierunek chiński”, ss. 61-63; „Własność nienaruszalna i święta”, ss. 113-115; „Bezprecedensowy powrót”, ss. 121-123; „Turcy na krawędzi wojny domowej”, ss. 141-143) mają na tle całości charakter incydentalny. Pozostałych w większości nie rozumiem. Wyraźnie natomiast dostrzegam pewną drażniącą tendencję: antyczne wątki zostały w pracy wykorzystane w sposób płytki i instrumentalny. W takim otoczeniu wszelkie zgłoszone w pracy postulaty, jakkolwiek by się do nich nie odnosić, już na starcie tracą wiarygodność (por. np. s. 59, 87, 122). Pamiętając o przywołanej na początku niniejszego wywodu opinii Cezanne'a, w miarę postępowania lektury „Powtórki z Rzymu”, coraz natarczywiej docierała do mnie brutalna prawda, z jakiego rodzaju osobowością przyszło mi obcować.

A może się mylę? Może nie odgadłem przemyślnego zamysłu autora, który sprytnie wystrychnął mnie na dudka? To przecież więcej niż możliwe, że źle zinterpretowałem wywołujące gęsią skórkę: toporny język, mętny wywód oraz idącą z nimi w parze trywializację poruszanej 
problematyki. A co, jeżeli był to zabieg zamierzony? Jeśli, pragnąc dotrzeć do niewyrobionego czytelnika, ksiądz profesor Franciszek Longchamps de Bérier świadomie zechciał przemówić do niego, jak do swojaka, głośno przyznaję się do błędu, a jemu należą się przeprosiny, pochwała i Order Uśmiechu.

Maciej Jońca*

* Katolicki Uniwersytet Lubelski Jana Pawła II. 